American Journal of Animal and Veterinary Sciences 5 (1): 13-19, 2010

ISSN 1557-4555

(C) 2010 Science Publications

\title{
Application of Meal Feeding and Skip-A-Day Feeding With or Without Probiotics for Broiler Chickens Grown at High-Altitude to Prevent Ascites Mortality
}

\author{
Ali Saffar and Fariborz Khajali \\ Department of Animal Science, Shahrekord University, \\ Postal Code: 88186-34141, Shahrekord, Iran
}

\begin{abstract}
Problem statement: Ascites is a common rapid-growth-related problem in broiler chickens grown at high altitude where the partial pressure of oxygen is low and is marginally adequate to support the growth performance and ascites-related variables. A mismatch between the growth of oxygen supplying organs and the oxygen demanding organs causes ascites in broiler chickens. In the present study, broilers were subjected to two types of feed restriction with or without probiotics and changes in the growth rate of body organs were attributed to the incidence of ascites. Approach: Four hundred male day-old broiler chicks were randomly assigned in a completely randomized design to five treatments: (1) a control group fed ad libitum throughout the experiment (2) a group subjected to meal feeding during 5-11 days of age with feeding times from 08-12 $\mathrm{h}$ and 13-17 $\mathrm{h}$, (3) a group similar to treatment 2 except to received probiotics, (4) a skip-a-day feeding with $24 \mathrm{~h}$ fasting on days 9 and 11 and (5) a group similar to treatment 4 except to received probiotics. Probiotics was only used during the feed restriction at $1 \mathrm{~g} \mathrm{~L}^{-1}$ in the drinking water. Broilers reared on litter flooring from 1-49 days of age. Results: Both feed restriction programs used under conditions of the experiment resulted in poorer performance relative to the full-fed control but retarded growth caught up at the end of experiment. Carcass and breast yield were significantly $(p<0.05)$ reduced right after feed restriction but not later on. Heart and liver percentages showed a reverse growth pattern after termination of feed restriction. Feed restriction had no consistent effect on abdominal fat deposition. Broilers subjected to the feed restriction had significantly $(\mathrm{p}<0.05)$ lower proportion of right ventricle to total ventricles. Probiotics had no beneficial impact on the compensatory growth though they tended to reduce the mortality from ascites. Conclusion: Early feed restriction did not influence the proportional growth of body organs and had no significant impact on ascites incidence. Probiotics had a positive effect in prevention of ascites.
\end{abstract}

Key words: Feed restriction, probiotics, broiler

\section{INTRODUCTION}

Pulmonary Hypertension Syndrome (PHS), is a condition commonly observed in commercial broilers frequently often referred to as "ascites". Despite considerable research efforts, its pathogenesis in fast growing broilers is poorly understood. Accordingly, proper environmental conditions and optimal nutritional strategies are needed to prevent the development of PHS in highly susceptible broilers (Khajali et al., 2007; Izadinia et al., 2010).

Feed restriction programs are usually used in broiler production to prevent metabolic diseases and leg deformities (Julian, 2000). Research has shown that the timing, duration and severity of the restriction have an impact on whether a bird is able to obtain body weight consistent with unrestricted birds or cope with the retarded growth (Khajali et al., 2007). Feed restriction programs are often applied by limiting the quantity of feed allowed each day, or by shortening the length of feeding time (Demir et al., 2004). Skip-a-day feeding usually implements in broiler breeder production but it has been also used effectively in broiler chickens. An intensive skip-a-day feeding was used in broilers raised at high altitudes to prevent PHS but it imposed severe stress to birds and resulted in poor performance (Khajali et al., 2007). Meal feeding has been used and shown to be an effective feed restriction program in broiler production. The advantage of meal feeding compared to skip-a-day feed restriction program is that it is less stressful (Susbilla, 2003).

Most recently, Khajali and Fahimi (2010) reported a remarkable shift from developing oxidative tissues (thigh muscles) to glycolytic tissues (pectoralis

Corresponding Author: Fariborz Khajali, Department of Animal Science, Shahrekord University, Postal Code: 88186-34141, Shahrekord, Iran Tel: 98 (381) 222-4834 Fax: 98 (381) 442- 4428 
muscles) in broilers predisposing to ascites compared to the control group. This shift may reflect compatibility between oxygen economy and attenuating PHS. Feed restriction may influence the proportional growth of body organs. Considering the link between changes in body organs and the incidence of ascites, the present study was conducted to evaluate the growth patterns of body organs and its association with ascites in broilers subjected to two different feed restriction programs. As feed restriction programs impose stress to birds, the role of probiotics was also considered. Probiotics are microbial cell preparations or components of microbial cells that have a beneficial effect on health (Farnworth et al., 2005). Probiotics have shown to alleviate the stress caused by feed restriction and improve the immunocompetence of birds (Yurong et al., 2005).

\section{MATERIALS AND METHODS}

Four hundred day-old male broiler chicks (Ross 308) were randomly assigned to 20 groups of 20 birds kept on floor pens. Four such groups (replicates) were randomly assigned to each treatment. Five treatments were used as follow: (1) a control group with unlimited access to feed throughout the experiment (2) a group subjected to meal feeding during 5-11 days of age, (3) a group similar to treatment 2 except that received probiotics at $1 \mathrm{~g} \mathrm{~L}^{-1}$ in the drinking water during meal feeding period. (4) a skip-a-day feeding with $24 \mathrm{~h}$ fasting on days 9 and 11 and (5) a group similar to treatment 4 except that received probiotics at $1 \mathrm{~g} \mathrm{~L}^{-1}$ in the drinking water during fasting intervals. Meal feeding was applied by allowing birds to access the feed in $24 \mathrm{~h}$ intervals a day during the aforementioned period (08-12 and 13-17 h). During meal time, feed was available in mesh form at will. After termination of feed restriction, all chicks received the same control diet to the end of experiment. Diets were formulated to meet the nutrient requirements of NRC (National Research Council, 1994). The composition of the diets in different stages is shown in Table 1. Probiotics consisted of seven bacterial strains (L. acidophilus, L. delbrueckii, L. plantarum, L. rhamnosus, Entococcus faecium, Streptococcus thermophilus and Bifidiobacterium bifidum) and two fungus strains (Aspergillus oryzae and Candida pintolopesii). Addition of probiotics to the tap water was conducted on daily basis to ensure maximum survivability of microorganisms. The survival rate of microorganisms is sustained for $12 \mathrm{~h}$ when administered as liquid suspensions (recommended by Nikootec Co. Tehran, Iran).
Table 1: Composition of the experimental diets (\%) in different stages

\begin{tabular}{lccc}
\hline Ingredient & $\begin{array}{l}\text { Starter } \\
(1-21 \text { day })\end{array}$ & $\begin{array}{l}\text { Grower } \\
(21-42 \text { day })\end{array}$ & $\begin{array}{l}\text { Finisher } \\
(42-49 \text { day })\end{array}$ \\
\hline Corn & 63.50 & 70.00 & 73.45 \\
Soybean meal $(42 \% \mathrm{CP})$ & 28.50 & 24.00 & 19.50 \\
Fish meal & 5.00 & 3.00 & 3.00 \\
Dicalcium phosphate & 1.00 & 0.85 & 0.60 \\
Oyster shell & 1.20 & 1.30 & 1.50 \\
DL-Methionine & 0.05 & - & 0.05 \\
Mineral premix ${ }^{1}$ & 0.25 & 0.25 & 0.25 \\
Vitamin premix & 0.25 & 0.25 & 0.25 \\
Salt & 0.30 & 0.25 & 0.20 \\
sand & - & - & 1.20 \\
Calculated ME $\left(\mathrm{kcal}^{2} \mathrm{~kg}^{-1}\right)$ & 2900.00 & 2950.00 & 2970.00 \\
Determined CP $(\%)$ & 20.60 & 18.30 & 16.90 \\
\hline T. Provided the following & per kilogram of diet: & Mn
\end{tabular}

${ }^{1}$ : Provided the following per kilogram of diet: $\mathrm{Mn}$ (from $\mathrm{MnSO}_{4} \cdot \mathrm{H}_{2} \mathrm{O}$ ), $40 \mathrm{mg}$; $\mathrm{Zn}$ (from $\mathrm{ZnO}$ ), $40 \mathrm{mg}$; $\mathrm{Fe}$ (from $\mathrm{FeSO}_{4} \cdot 7 \mathrm{H}_{2} \mathrm{O}$ ), $20 \mathrm{mg}$; $\mathrm{Cu}$ (from $\mathrm{CuSO}_{4} \cdot 5 \mathrm{H}_{2} \mathrm{O}$ ), $4 \mathrm{mg}$; I (from Ca $\left(\mathrm{IO}_{3}\right)_{2} \cdot \mathrm{H}_{2} \mathrm{O}$ ), $0.64 \mathrm{mg}$; $\mathrm{Se}, 0.08 \mathrm{mg}$ (from sodium selenite); ${ }^{2}$ : Provided the following $\mathrm{kg}^{-1}$ of diet: Vitamin A (trans-retinyl acetate), 3600IU; vitamin $\mathrm{D}_{3}$ (cholecalciferol), $800 \mathrm{IU}$; vitamin E (DL- $\alpha$-tocopheryl acetate), $7.2 \mathrm{mg}$; vitamin $\mathrm{K}_{3}, 1.6 \mathrm{mg}$; vitamin $\mathrm{B}_{1}, 0.72 \mathrm{mg}$; vitamin $\mathrm{B}_{2}, 3.3 \mathrm{mg}$; vitamin $\mathrm{B}_{3}, 0.4 \mathrm{mg}$; vitamin $\mathrm{B}_{6}, 1.2 \mathrm{mg}$; vitamin $\mathrm{B}_{12}, 0.6 \mathrm{mg}$; folic acid, $0.5 \mathrm{mg}$; choline chloride, $200 \mathrm{mg}$

Chicks were maintained on a $24 \mathrm{~h}$ constant lighting regime. The initial room temperature was $32 \pm 1^{\circ} \mathrm{C}$ and decreased in a stepwise fashion so that it was $28^{\circ} \mathrm{C}$ by day $7,24^{\circ} \mathrm{C}$ by day 14 and $20^{\circ} \mathrm{C}$ by day 21 and thereafter. Body weight and feed consumption were recorded on weekly basis and feed conversion ratio was calculated taking into account the mortality weights during compensatory period (12-49 day). On days 12 , 22, 32 and 42 after $4,6,8$ and $10 \mathrm{~h}$ starvation, respectively, 8 chicks from each group were weighed, killed by decapitation and their organs weighted.

Before the time of slaughter, the body weight of each bird was measured. When the head, shanks and feet and feathers were removed, the carcass was eviscerated by cutting around the vent to remove all of the viscera. As much as possible, the abdominal fat pad was left intact and attached to the carcass. Once eviscerated, the carcass without giblets was weighed and expressed as a percentage of its initial live weight and considered as the carcass yield. Breast and thighs were weighted and expressed as percentages of eviscerated carcass weight. The weights of the liver, heart, lungs and abdominal fat were measured to the nearest $0.01 \mathrm{~g}$ and expressed as percentage of the initial live body weight.

All floor pens were checked daily for mortality. In order to confirm the mortality from ascites, postmortem examination was performed. All cases with the ratio of Right Ventricle to Total Ventricles (RV/TV) exceeded 0.299 considered as ascites (Walton et al., 2001). At the end of the experiment (49 days), five birds from each pen were killed for the determination of 
RV/TV. The experimental animals were kept, maintained and treated in accepted standards for the humane treatment of animals.

All data from each slaughter age were analyzed using the general linear means procedure of SAS software (SAS Institute, 1996). Duncan's multiple range test was used to separate the means.

\section{RESULTS}

Body weight changes among the treatments throughout the experiment are summarized in Table 2. Body weight at 2 and 5 days of age, which were beginning of experiment and applying the meal feeding, respectively, is not different as no treatment has applied yet. At 9 day, birds experienced meal feeding had significantly $(\mathrm{p} \leq 0.05)$ lower body weight than other groups, which had not subjected to any treatment. Meal feeding for 4 days dropped $15.8 \%$ of body weight in meal-fed groups relative to the full-fed control. On day 12, which was just after termination of meal feeding and skip-a-day feeding, all feed-restricted groups had significantly $(\mathrm{p} \leq 0.05)$ lower body weight compared to the full-fed control. The differences between the feedrestricted groups with their corresponding probioticreceived groups were very little (131.9 Vs $130.6 \mathrm{~g}$ and
119.4 Vs $119.5 \mathrm{~g}$ for meal-fed and skip-a-day fed groups, respectively). This indicates that the meal feeding and the skip-a-day feeding used under the condition of the experiment resulted in 20.8 and $28 \%$ in body weigh relative to the full-fed control. During realimentation period (12-49 day), body weight changes were frequently monitored to find out the time to attain catch-up growth. As indicated in Table 2, body weight of birds subjected to either feed restrictions were significantly $(\mathrm{p} \leq 0.05)$ lower than the full-fed control. However, no significant difference was found among the treatments with respect to body weight on day 42 and 49. On 49 day, reduction in body weight of feed restricted groups in relation to the full-fed control ranged from nearly $0-4.8 \%$. The effect of probiotic was neither consistent nor significant.

Table 3 and 4 depict the effects of meal feeding and skip-a-day feeding with or without probiotics on weight gain and feed consumption, respectively, during feed restrictions, compensatory growth and throughout the experiment. Weight gain and feed intake of birds on restricted feeding were significantly lower than the fullfed control in 5-12 and 9-12 day. However, no significant difference was observed among the treatments during compensatory growth (12-49 day) and whole (2-49 day) periods of the experiment.

Table 2: Effect of meal feeding and probiotics on body weight of different treatments throughout the experiment $\left(\mathrm{g} \mathrm{b}^{-1}\right)$

\begin{tabular}{|c|c|c|c|c|c|c|}
\hline Days & Control & Meal fed & Meal fed + Probiotic & Skip-a-day & Skip-a-day + probiotic & SEM \\
\hline 2 & 47.2 & 47.3 & 47.2 & 47.4 & 47.3 & 0.07 \\
\hline 5 & 64.4 & 65.1 & 64.5 & 63.9 & 64.5 & 0.54 \\
\hline 9 & $113.6^{\mathrm{a}}$ & $95.6^{\mathrm{b}}$ & $95.5^{\mathrm{b}}$ & $115.5^{\mathrm{a}}$ & $114.1^{\mathrm{a}}$ & 1.39 \\
\hline 12 & $165.6^{\mathrm{a}}$ & $131.9^{\mathrm{b}}$ & $130.6^{\mathrm{b}}$ & $119.4^{\mathrm{c}}$ & $119.5^{\mathrm{c}}$ & 2.34 \\
\hline 14 & $234.7^{\mathrm{a}}$ & $205.5^{\mathrm{b}}$ & $201.3^{\mathrm{b}}$ & $196.5^{\mathrm{b}}$ & $200.8^{\mathrm{b}}$ & 4.20 \\
\hline 21 & $498.1^{\mathrm{a}}$ & $465.7^{\mathrm{b}}$ & $455.6^{\mathrm{b}}$ & $445.9^{b}$ & $450.9^{b}$ & 8.44 \\
\hline 28 & $819.9^{\mathrm{a}}$ & $791.8^{\mathrm{ab}}$ & $778.6^{\mathrm{b}}$ & $763.0^{\mathrm{b}}$ & $762.0^{\mathrm{b}}$ & 10.93 \\
\hline 35 & $1266.2^{\mathrm{a}}$ & $1197.4^{b}$ & $1206.0^{\mathrm{b}}$ & $1188.8^{\mathrm{b}}$ & $1182.2^{\mathrm{b}}$ & 18.99 \\
\hline 42 & 1816.5 & 1733.4 & 1764.0 & 1789.2 & 1718.4 & 36.58 \\
\hline 49 & 2440.8 & 2323.4 & 2369.0 & 2426.9 & 2345.8 & 58.89 \\
\hline
\end{tabular}

Table 3: Effect of meal feeding and probiotics on body weight gain among the treatments at different stages of the experiment $\left(\mathrm{g} \mathrm{b}^{-1}\right)$

\begin{tabular}{lccc}
\hline Treatment & $5-12$ days & $9-12$ days & $12-49$ days \\
\hline Control & $101.20^{\mathrm{a}}$ & $52.10^{\mathrm{a}}$ & 2275.10 \\
Meal fed & $66.75^{\mathrm{b}}$ & $36.20^{\mathrm{b}}$ & 2186.10 \\
Meal fed + probiotic & $66.17^{\mathrm{b}}$ & $35.20^{\mathrm{b}}$ & 22393.10 \\
Skip-a-day & $55.60^{\mathrm{c}}$ & $3.95^{\mathrm{c}}$ & 2239.10 \\
Skip-a-day + probiotic & $55.40^{\mathrm{c}}$ & $5.50^{\mathrm{c}}$ & 2321.10 \\
SEM & 2.38 & 1.41 & 2231.90 \\
\hline
\end{tabular}

$\overline{\mathrm{a}, \mathrm{b}, \mathrm{c}}$ : Means in each row with no common superscripts differ significantly $(\mathrm{p}<0.05)$

Table 4: Effect of meal feeding and probiotics on feed intake among the treatments at different stages of the experiment $\left(\mathrm{g} \mathrm{b}^{-1}\right)$

\begin{tabular}{llrr}
\hline Treatment & $5-12$ day & $9-12$ day & $12-49$ day \\
\hline Control & $166.90^{\mathrm{a}}$ & $90.00^{\mathrm{a}}$ & 4882.70 \\
Meal fed & $119.90^{\mathrm{b}}$ & $62.80^{\mathrm{b}}$ & 5075.30 \\
Meal fed + probiotic & $120.60^{\mathrm{b}}$ & $62.30^{\mathrm{b}}$ & 4752.60 \\
Skip-a-day & $116.20^{\mathrm{b}}$ & $37.10^{\mathrm{c}}$ & 4843.50 \\
Skip-a-day + probiotic & $114.80^{\mathrm{b}}$ & $37.40^{\mathrm{c}}$ & 4700.50 \\
SEM & 1.51 & 1.44 & 498.10 \\
a,b,c: Means in each row with no common superscripts differ significantly $(\mathrm{p}<0.05)$ & 58900 \\
\end{tabular}


American J. Animal \& Vet. Sci., 5 (1): 13-19, 2010

Table 5: Effect of meal feeding and probiotics on feed conversion ratio of broilers during compensatory period

\begin{tabular}{lllllll}
\hline Variables & Control & Meal fed & Meal fed + probiotic & Skip-a-day & Skip-a-day + probiotic & SEM \\
\hline FCR 12-49 day & 2.15 & 2.18 & 2.17 & 2.11 & 2.15 & 0.031 \\
\hline Means in each row with no common superscripts differ significantly $(\mathrm{p}<0.05)$ & &
\end{tabular}

Means in each row with no common superscripts differ significantly $(\mathrm{p}<0.05)$

Table 6: Effect of meal feeding and probiotics on allometric growth of body organs

\begin{tabular}{|c|c|c|c|c|c|c|}
\hline Treatment & Carcass (\%) & Breast $(\%)$ & Thighs (\%) & Liver $(\%)$ & Heart $(\%)$ & Abdominal fat (\%) \\
\hline \multicolumn{7}{|l|}{12 day } \\
\hline Control & $0.440^{\mathrm{a}}$ & $24.30^{\mathrm{a}}$ & 30.30 & $3.37^{\mathrm{abc}}$ & 1.670 & - \\
\hline Meal feeding & $0.400^{\mathrm{b}}$ & $22.90^{\mathrm{ab}}$ & 29.90 & $3.58^{\mathrm{a}}$ & 1.570 & - \\
\hline Meal + probiotic & $0.400^{\mathrm{b}}$ & $23.90^{\mathrm{ab}}$ & 28.90 & $3.08^{\mathrm{c}}$ & 1.520 & - \\
\hline Skip-a-day & $0.370^{\mathrm{b}}$ & $21.50^{\mathrm{b}}$ & 30.80 & $3.47^{\mathrm{ab}}$ & 1.570 & - \\
\hline Skip + probiotic & $0.390^{\mathrm{b}}$ & $22.40^{\mathrm{ab}}$ & 29.80 & $3.12^{\mathrm{c}}$ & 1.580 & - \\
\hline SEM & 0.010 & 0.28 & 0.87 & 0.11 & 0.080 & - \\
\hline \multicolumn{7}{|l|}{22 day } \\
\hline Control & 0.640 & 28.40 & 27.70 & 2.94 & $1.020^{\mathrm{b}}$ & 0.70 \\
\hline Meal feeding & 0.620 & 27.50 & 27.40 & 2.99 & $1.090^{\mathrm{ab}}$ & 0.66 \\
\hline Meal + probiotic & 0.630 & 29.00 & 27.50 & 3.20 & $1.110^{\mathrm{ab}}$ & 0.69 \\
\hline Skip-a-day & 0.620 & 28.10 & 28.30 & 2.91 & $1.100^{\mathrm{ab}}$ & 0.68 \\
\hline Skip + probiotic & 0.630 & 28.20 & 28.30 & 3.06 & $1.160^{\mathrm{a}}$ & 0.68 \\
\hline SEM & 0.006 & 0.74 & 0.50 & 0.10 & 0.030 & 0.09 \\
\hline \multicolumn{7}{|l|}{32 day } \\
\hline Control & 0.670 & 28.30 & 28.80 & 2.51 & 1.000 & $1.17^{\mathrm{b}}$ \\
\hline Meal feeding & 0.660 & 27.70 & 29.20 & 2.32 & 1.070 & $1.73^{\mathrm{a}}$ \\
\hline Meal + probiotic & 0.670 & 27.60 & 29.30 & 2.47 & 1.100 & $1.38^{\mathrm{ab}}$ \\
\hline Skip-a-day & 0.670 & 26.40 & 29.20 & 2.46 & 1.060 & $1.50^{\mathrm{ab}}$ \\
\hline Skip + probiotic & 0.660 & 27.60 & 29.40 & 2.51 & 1.070 & $1.50^{\mathrm{ab}}$ \\
\hline SEM & 0.005 & 0.63 & 0.29 & 0.08 & 0.045 & 0.15 \\
\hline \multicolumn{7}{|l|}{42 day } \\
\hline Control & 0.700 & 29.60 & 29.00 & 1.99 & 0.680 & $1.86^{\mathrm{ab}}$ \\
\hline Meal feeding & 0.690 & 29.10 & 29.70 & 2.08 & 0.700 & $1.58^{\mathrm{b}}$ \\
\hline Meal + probiotic & 0.700 & 30.50 & 28.30 & 2.06 & 0.710 & $1.72^{\mathrm{b}}$ \\
\hline Skip-a-day & 0.690 & 30.30 & 28.90 & 2.15 & 0.680 & $2.17^{\mathrm{a}}$ \\
\hline Skip + probiotic & 0.690 & 30.00 & 29.10 & 2.17 & 0.670 & $1.69^{\mathrm{b}}$ \\
\hline SEM & 0.007 & 0.76 & 0.51 & 0.08 & 0.030 & 0.13 \\
\hline
\end{tabular}

a,b,c: Means carry different superscripts within each column at designated slaughter day differ significantly $(\mathrm{p}<0.05)$; Abdominal fat was neglectable at 12 day

Table 7: Effect of meal feeding and probiotics on RV: TV and mortality from ascites

\begin{tabular}{llllll}
\hline Variables & Control & Meal fed & Meal fed + probiotic & Skip-a-day & Skip-a-day + probiotic \\
\hline RV/TV & $0.21 \pm 0.007^{\mathrm{a}}$ & $0.19 \pm 0.007^{\mathrm{b}}$ & $0.18 \pm 0.007^{\mathrm{b}}$ & $0.19 \pm 0.007^{\mathrm{b}}$ & $0.17 \pm 0.007^{\mathrm{b}}$ \\
Ascites mortality & $6.25(5 / 80)$ & $5.0(4 / 80)$ & $0(0 / 80)$ & $5.00(4 / 80)$ & $1.25(1 / 80)$ \\
\hline $\mathrm{a}, \mathrm{b}$. Means in each row $w i t h$ no common & superscripts differ significantly $(\mathrm{p}<0.05) ; \mathrm{RV} / \mathrm{TV}$ : The weight ratio of Right Ventricle/Total Ventricles
\end{tabular}

$\overline{a, b}$ : Means in each row with no common superscripts differ significantly ( $\mathrm{p}<0.05)$; RV/TV: The weight ratio of Right Ventricle/Total Ventricles

Feed conversion ratio during the compensatory growth for the control, meal fed, meal-fed + probiotic, skip-a-day and skip-a-day + probiotic was 2.15, 2.18, 2.16, 2.11 and 2.16, respectively. Differences between the treatments were not significant $(p \leq 0.05)$ (Table 5).

Of interesting finding was allometric growth of some body organs. When measured just after feed restriction (Day 12), carcass yield was significantly $(\mathrm{p} \leq 0.05)$ reduced by both meal feeding and skip-a-day feeding. However, birds subjected to feed restriction could attain carcass yield comparable to those on the control group later on so that no significant difference was found among the treatments at 22, 32 and 42 day. Likewise, breast yield was significantly $(\mathrm{p} \leq 0.05)$ decreased as a result of skip-a-day feeding and tended to decrease by meal feeding when measured on day 12 (upon completion of feed restriction). However, birds experienced feed restriction could obtain breast yield as comparable as those on the control group later on (Table 6). Percentage of thighs relative to carcass did not influenced by meal feeding or skip-a-day feeding. Conversely, percentage of liver was significantly increased $(\mathrm{p} \leq 0.05)$ in feed restricted groups which received no probiotic right after feed restriction whereas it did not changed in other feed-restricted groups received probiotic. Heart percentage tended to decrease but not significantly immediately after feed restriction. Nevertheless, the percentage of heart began to increase thereafter up to 42 day, when it equalized with that of the control. The feed restriction regimes had no consistent effect on abdominal fat deposition (Table 6).

Mortality from ascites and RV: TV are indicated in Table 7. Broilers subjected to the feed restrictions had 
significantly lower RV: TV than the control. There were no remarkable difference between probioticreceived groups and their corresponding controls (feedrestricted groups without probiotics). Total mortality from ascites was not high enough to get it into statistical analysis. Cumulative mortality from ascites ranged from 0-5 birds among the treatments. Total number of mortality from ascites throughout the experiment was 5, 4, 0, 4 and 1 out of 80 birds in the control, meal-fed, meal-fed + probiotic, skip-a-day and skip-a-day + probiotic, respectively.

\section{DISCUSSION}

Both meal feeding and skip-a-day feeding used under the condition of the experiment caused considerable reduction in BW. However, the skip-a-day feeding with 2 days off was more severe than the meal feeding. The reduction in BW was obviously due to reduced feed intake as feed intake was partially or completely ceased. Feed intake in the compensatory growth period (12-49 day) did not differ between the full fed and feed restricted groups. This implies that catch-up growth occurred by improved feed efficiency in birds experienced feed restriction. In the other word, catch-up growth was not achieved by enhanced feed consumption. The reductions in body weight as affected by the feed restriction programs overcame by the end of experiment indicating a successful catch-up growth occurred.

Probiotics could not avoid of reduction in BW due to the feed restriction programs. The effect of probiotics on body weight changes has been reported to be controversial. There are reports suggesting no impact of probiotics on BW (Priyankarage et al., 2003). On the other hand, some reports showed beneficial effects of probiotics on BW (Zulkifli et al., 2000). This discrepancy might be related to the strain of bacteria, dosage and concentration of bacteria used, the form of bacteria (viability, dryness or their products) and the methods of using probiotics (Kalavathy et al., 2003). Probiotics have more beneficial effects when administered in the feed rather than the drinking water because the fermentation of feed in luminal tract helps the live organisms for more convenient colonization. This can explain the lack of positive response to probiotics in this experiment. No significant difference among the treatments with respect to FCR can be explained by the fact that both weight gain and feed intake reduced simultaneously. This finding is in accordance with other reports (Priyankarage et al., 2003).
Proportional growth of the body organs was of highly interest. Upon completion of feed restriction, carcass yield was significantly reduced by the feed restrictions. This reduction was mainly attributed to reduction in breast. Breast yield was significantly decreased right after feed restriction. Breast meat accounts for about one-third of total edible broiler meat. Thus, a very important part of each feed restriction program is achieving body weight loss especially breast in compensatory growth period. Results reported herein show that birds experienced feed restriction could obtain breast yield as comparable as those on the control group afterward. Percentage of liver was significantly increased $(p \leq 0.05)$ in feed restricted groups which received no probiotics right after feed restriction. This implies that gluconeogenesis intensively occurred in the liver. Liver is the primary site of gluconeogenesis in birds (Kouba et al., 1992). Realimentation normalized the size of liver indicating the rate of gluconeogenesis got slowed down. Heart percentage showed an interesting proportional growth trend after feed deprivation. It tended to decrease by feed restriction but began to increase afterward. The obvious and significant change attributable to the heart was that heart weight relative to body weigh began to increase during realimentation. A significant difference among the treatments is observed on day 22. This indicates a higher intensive metabolism in the feedrestricted birds than those of the control during the compensatory growth period which acquired more cardiac output.

The feed restriction regimes had no consistent effect on abdominal fat deposition. Controversial results have been reported with regard to abdominal fat deposition as affected by feed restriction. Some researchers reported a decreased trend for fat deposition (Jones and Farrell, 1992), whereas others reported opposite results (Lippens et al., 2000). The discrepancies might be due to the metabolic programming whereby early malnutrition leads to adult life obesity. The metabolism programming is induced by nutritional experience during the critical period in development with consequences later in adulthood (Patel and Srinivasan, 2002). It has been reported in humans that the tendency to store abdominal fat might be a persisting response to adverse conditions and growth failure in fetal life and infancy (GonzalezBarranco and Rios-Torres, 2004).

The proportion of $\mathrm{RV}$ : $\mathrm{TV}$ is an index of pulmonary hypertension. When this ratio exceeds 0.25 , it is said that chickens are suffering from pulmonary hypertension. Elevated RV: TV ratio in full-fed chickens than those on the feed restriction implies that 
these birds are more susceptible to ascites. The tendency to increase RV: TV in full-fed chickens, may indicate the advantage of implementing the feed restriction programs. This has been speculated in higher number of mortality from ascites. The interesting result was lower number of ascetic mortality in probiotic-received groups. This might be related to reduced ammonia production in the intestine which has decreased the incidence of ascites. The correlation between intestinal ammonia and ascites mortality has been documented.

\section{CONCLUSION}

Meal feeding for a week by allowing birds to feed in two $4 \mathrm{~h}$ intervals and skip-a-day feeding with two days off brought about 20.8 and $28 \%$ in body weigh relative to the full-fed control but retarded growth caught up to 42 days of age. Carcass and breast yield when measured right after feed restriction were significantly $(p \leq 0.05)$ reduced by any type of feed restriction but restored to the extent comparable to the control afterward. Heart percentage tended to decrease but not significantly immediately after feed restriction and it began to increase afterward to the extent similar to the control at 42 day. However, RV: TV significantly reduced by either type of feed restriction. Liver percentage, however, showed a reverse trend. Feed restriction had no consistent effect on abdominal fat deposition. Probiotics had no beneficial impact on the compensatory growth but tended to decrease the incidence of ascites.

\section{ACKNOWLEDGEMENT}

Researchers wish to thank Shahrekord University for funding this research.

\section{REFERENCES}

Demir, E., S. Sarica, A. Sekeroglu, M.A. Ozcan and Y. Seker, 2004. Effects of early and late feed restriction or feed withdrawal on growth performance, ascites and blood constituents of broiler chickens. Acta Agric. Scand, 54: 152-258. DOI: 10.1080/09064700410004852

Farnworth, E.R., 2005. The Beneficial health effects of fermented foods-potential probiotics around the world. J. Neutrac. Func. Med. Foods, 4: 93-117. DOI: $10.1300 / J 133 v 04 n 03 \_07$

Gonzalez-Barranco, J. and J.M. Rios-Torres, 2004. Early malnutrition and metabolic abnormalities later in life. Nutr. Rev., 62: S134-S139. DOI: 10.1301/nr.2004.jul.S134-S139
Izadinia, M., M. Nobakht, F. Khajali, M. Faraji, F. Zamani, D. Qujeq and I. Karimi, 2010. Pulmonary hypertension and ascites as affected by dietary protein source in broiler chickens reared in cool temperature at high altitudes. Anim. Feed Sci. Tech. (In press).

Jones, G.P.D. and D.J. Farrell, 1992. Early-life food restriction of broiler chickens: II. Effects of food restriction on the development of fat tissue. $\mathrm{Br}$. Poult. Sci., 33: 589-601. DOI: 10.1080/00071669208417498.

Julian, R.J., 2000. Physiological, management and environmental triggers of the ascites syndrome: A review. Avian Pathol., 29: 519-527. DOI: 10.1080/03079450020016751.

Kalavathy, R., N. Abdullah, S. Jalaludin and Y.W. Ho, 2003. Effects of lactobacillus cultures on growth performance, abdominal fat deposition, serum lipids and weight of organs of broiler chickens. Br. Poult. Sci., 44: 139-144. DOI: 10.1080/0007166031000085445

Khajali, F. and S. Fahimi, 2010. Influence of dietary fat source and supplementary $\alpha$-tocopheryl acetate on pulmonary hypertension and lipid peroxidation in broilers. J. Anim. Phyiol. Anim. Nutr. (In press)

Khajali, F., A.K. Zamani Moghaddam and E.A. Khoshouie, 2007. Application of an early skip-a-day feed restriction on physiological parameters, carcass traits and development of ascites in male broilers reared under regular or cold temperatures at high altitude. Anim. Sci. J., 78: 159-163. DOI: 10.1111/j.1740-0929.2007.00420.x.

Kouba, M., D. Catheline and B. Leclercq, 1992. Lipogenesis in turkeys and chickens: A study of body composition and liver lipogenic enzyme activities. Br. Poult. Sci. 33: 1003-1014. DOI: 10.1080/00071669208417543.

Lippens, M., G. Room, G. De Groote and E. Decuypere, 2000. Early and temporary quantitative food restriction of broiler chickens. 1. Effects on performance characteristics, mortality and meat quality. Br. Poult. Sci., 41: 343-354. DOI: 10.1080/713654926

National Research Council, 1994. Nutrient Requirements for Poultry. 9th Review Edn., NRC publications. NY.

Patel, M.S. and M. Srinivasan, 2002. Metabolic programming: Causes and consequences. J. Biol. Chem., 277: 1629-1632. DOI 10.1074/jbc.R100017200. 
Priyankarage, N., S.S.P. Silva, S.P. Gunaratne, H. Kothalawala, M.W.C.D. Palliyaguru and G.A. Gunawardana, 2003. Efficacy of probiotics and their effects on performance, carcase characteristics, intestinal microflora and Salmonella incidence in broilers. Br. Poult. Sci. 44: S26-S27. DOI: 10.1080/713655283

SAS Institute, 1996. SAS User's Guide: Statistics SAS Institute Inc., Cary, NC.

Susbilla, J.P., I. Tarvid, C.W. Gow and T.L. Frankel, 2003. Quantitative feed restriction or meal-feeding of broiler chicks alter functional development of enzymes for protein digestion. Br. Poult. Sci., 44: 698-709.

DOI: $10.1080 / 00071660310001643679$
Walton, J.P., R.J. Julian and E.J. Squires, 2001. The effects of dietary flax oil and antioxidants on ascites and pulmonary hypertension in broiler chickens using a low temperature model. Br. Poult. Sci., 42: 123-129. DOI: 10.1080/00071669987494

Yurong, Y., S. Ruiping, Z. Shimin and J. Yibao, 2005. Effect of probiotics on intestinal mucosal immunity and ultrastructure of cecal tonsils of chickens. Arch. Anim. Nutr. 59: 237-246. DOI: 10.1080/17450390500216928

Zulkifli, J., N. Abdullah, N.M. Azrim and Y.W. Ho, 2000. Growth performance and immune response of two commercial broiler strains fed diet containing Lactobacillus culture and oxytetracycline underheat stress conditions. Br. Poult. Sci., 41: 593-597. DOI: 10.1080/713654979 